\title{
Development of Indonesian Wellhead Generating Unit (Small Scale) Based on Legal and Regulation of PT. Geo Dipa Dieng: A Case Study
}

\author{
Akhmad Sofyan ${ }^{1, *}$ Hari Sumantri Aka ${ }^{1}$ Ade Maulana Rizaldy ${ }^{1}$ Bambang Yudho
}

\author{
Suranta ${ }^{1}$
}

\author{
${ }^{I}$ Oil and Gas Production Engineering, Polytechnic of Energy and Mineral Akamigas, Cepu Blora-Central Java, \\ Indonesia \\ *Corresponding author.Email: akhmads@esdm.go.id
}

\begin{abstract}
Geothermal energy is one of the environmentally friendly energies to generate electricity. Heat energy in the form of steam and hot water in the earth is flowed to the surface and into production facilities and generators to produce electrical energy. Currently there are many types of power plants for geothermal, such as half cycle, single flash, double flash, binary cycle and combined cycle. This type of generator is a power plant with a capacity of 65-110 MWe and requires a large area, many wells, large facilities and of course large capital. However, there is a type of generator that can be developed quickly, namely the Wellhead Generating Unit PLTP. In the manufacture of the Well Head Generating Unit, steam is extracted from the well and converted into electricity at the wellhead. This type of generator can generate electricity in a relatively short time and with simpler equipment. Indonesia only has one example of developing a Wellhead Generating Unit (Small Scale), namely PLTP PT. Geo Dipa Energi Dieng with a capacity of 10 MWe. The method used in this paper is a literature study of geothermal regulations in Indonesia. Here are some regulations governing geothermal energy in Indonesia, namely Law Number 21 of 2014 concerning Geothermal, Presidential Regulation Number 3 of 2016 concerning Acceleration of Implementation of National Strategic Projects, Government Regulation Number 7/2017 concerning Geothermal Energy for Indirect Use, aspects of land clearing are regulated in Law number 4/2009 on Minerba. The sale and purchase agreement are regulated in the Minister of Energy and Mineral Resources Regulation Number 10 of 2017 and the environmental impact is regulated in the Government Regulation of the Republic of Indonesia Number 27 of 1999 concerning Environmental Impact Analysis. Enacted on May 7, 1999. From the above regulations, the Wellhead Generating Unit (Small Scale) is the same as an ordinary conventional generator, namely a permit to use indirect geothermal energy to generate electricity, but what distinguishes only the capacity generated by this generator and the surface facilities used.
\end{abstract}

Keywords: Geothermal Energy, Well Head Generating Unit, Law, Presidential Regulation, Government Regulation.

\section{INTRODUCTION}

Geothermal energy is one of the environmentally friendly energies to generate electricity. Heat energy in the form of steam and hot water that is inside the earth is flowed to the surface and into production and generating facilities to generate electrical energy. Currently, there are many types of electricity generation for geothermal, such as half cycle, single flash, double flash, binary cycle, and combined cycle. These types of generators are power plants with a large capacity of 65-110 MWe for one unit.
So, it requires a large area, many wells, large facilities and of course large capital. However, there is a type of power plant that does not require many wells and large facilities and can be developed quickly namely the Wellhead Generating Unit type geothermal power plant.

The number of obstacles related to geothermal development in Indonesia is the cause of the minimal utilization of geothermal energy, especially for developing the Wellhead Generating Unit. In addition to technical issues, many still do not know about the legal 
and regulatory agreements for small capacity geothermal plants, considering that the Wellhead Generating Unit can be one of the answers to increasing the installed capacity of geothermal plants in Indonesia. In Indonesia, there is only one example of developing a Wellhead

Generating Unit (Small Scale), namely PLTP PT. Geo Dipa Energi Dieng with a capacity of $10 \mathrm{MWe}$.

Geothermal energy is environmentally friendly with great potential and its utilization is not optimal, so it needs to be encouraged and increased in a planned and integrated manner in order to reduce dependence on fossil energy. Here are some regulations governing geothermal energy in Indonesia:

a. Law No. 21 of 2014 concerning Geothermal Energy;

b. Government Regulation No. 7/2017 concerning Geothermal for Indirect Use;

c. Presidential Regulation No. 3 of 2016 concerning the Acceleration of the Implementation of National Strategic Projects;

d. ESDM Regulation No. 11/2009 concerning the Implementation of Geothermal Business Activities;

e. ESDM Regulation No. 17/2014 concerning Purchase of Electricity from PLTP and Geothermal Steam for PLTP by PT Perusahaan Listrik Negara (Persero);

f. ESDM Regulation No. 49/2017 concerning Amendments to the Minister of Energy and Mineral Resources Regulation No. 10/2017 concerning the Principles of the Power Purchase Agreement;

g. ESDM Regulation No. 50/2017 concerning Utilization of EBT Sources for Provision of Electricity

h. Ministerial regulation:

- Permen ESDM No. 11/2009 concerning the Implementation of Geothermal Business Activities;

- Permen ESDM No. 17/2014 concerning Purchase of Electricity from PLTP and Geothermal Steam for PLTP by PT Perusahaan Listrik Negara (Persero);

- Permen ESDM No. 40/2014 concerning the Fourth Amendment to the Regulation of the Minister of Energy and Mineral Resources Number 15 of 2010 concerning the List of Projects for Accelerated Development of Power Plants Using Renewable Energy, Coal and Natural Gas and Related Transmissions;
- Permen ESDM No. 44/2016 concerning Forms and Procedures for Placement and Disbursement of Geothermal Exploration Commitments;

- LHK Regulation No. P.46 / Menlhk / Setjen / KUM.1 / 5/2016 concerning Utilization of Environmental Services;

- Permen ESDM No. 21/2017 concerning Management of Mud Waste and Drill Cutting in Geothermal Drilling;

- Permen ESDM No. 23/2017 concerning Procedures for Reconciliation, Deposit and Reporting of Geothermal Production Bonuses;

- Permen ESDM No. 36/2017 concerning Procedures for Geothermal PSP and PSPE;

- Permen ESDM No. 37/2017 concerning Geothermal Working Area for Indirect Use;

- Permen ESDM No. 49/2017 concerning Amendments to the Minister of Energy and Mineral Resources No. 10/2017 concerning the Principles in the Power Purchase Agreement;

- Permen ESDM No. 50/2017 concerning Utilization of EBT Sources for Provision of Electricity

In the manufacture of the Wellhead Generating Unit (Figure 1), steam is extracted from the well and converted to electricity at the wellhead. In this way there is little steam transmission and thus no steam field development except for brine and cooling tower blowdown exhaust systems. Wellhead generators can be of the Back Pressure, Condensing or Combined Cycle type and consist of a turbo-generator, cooling tower, condenser, gas extraction system, electrical and control systems and additional equipment.

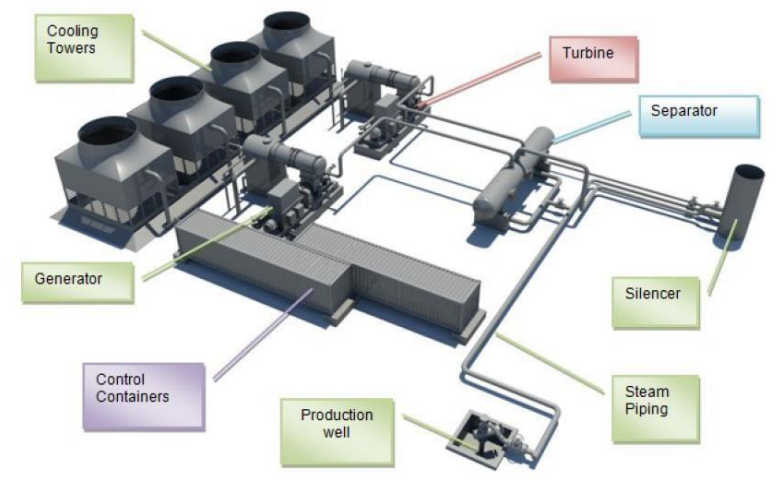

Figure 1 Schematic of Geothermal Wellhead Generating Unit

The advantages of a wellhead generating unit include 
a. The wellhead generating unit can be operated faster, that is, within 1-2 months. Meanwhile, the central plant usually can only be operated 6-7 years after drilling the first well.

b. By using small wellhead generator units, national private companies can be involved in geothermal companies.

c. The Wellhead Generating Unit can be used in areas where the topography is quite complicated because by using this unit, the steam flow pipe is much shorter when compared to the flow pipe in the central power plant.

d. A Wellhead Generating Unit can be moved to another well location in just 1-2 months.

e. The small unit makes shut-in easy for maintenance purposes.

The disadvantages of the Wellhead Generating Unit include:

a. Wellhead Generating Unit is a new technology; therefore, the equipment is relatively expensive and there are limited spare parts on the market.

b. Installation of the Wellhead Generating Unit is carried out in one well pad so that more wells in one well pad will pose a challenge for the operation and maintenance team.

c. The operation of a small unit will cost more than a large unit.

d. Longer and impractical power transmission lines are required because many transformers and extensive transmission networks are required

\section{METHOD}

The research method used in solving the problem is as follows:

a. Literature Study Literature study begins by looking for existing literature sources on research objects or related ones in the form of books, papers, journals and others.

b. Parameters related to this are related to earth regulations in Indonesia related to the Wellhead Generating Unit

c. Collecting data, the data required under these conditions are: Government Regulations, Presidential Regulations and ESDM Regulations

PLTP Small Scale Dieng is Indonesia's first smallscale generator which is targeted to operate commercially by the end of 2020 and is expected to increase its electricity production supply by $130 \mathrm{MW}$. This additional supply is the fulfillment of Geo Dipa's obligation to develop the Dieng area contract up to $400 \mathrm{MW}$. This development is one of PT Geo Dipa Energi's Long Term Plans as a Geothermal SOE and a Special Mission Vehicle under the Ministry of Finance.

Based on the above case explanation, the method used in this research is a literature study of geothermal related regulations. There are several things that will be discussed in this matter, namely as follows:

Based on the above case explanation, the method used in this research is a literature study of geothermal related regulations. There are several things that will be discussed in this matter, namely as follows:

1. Licensing policy regarding the Wellhead Generating Unit

2. The business entity that developed the Wellhead Generating Unit

3. Rules regarding land clearing for the Wellhead Generating Unit

4. The Wellhead Generating Unit power purchase agreement

5. Rules for the Environmental Impact Analyst to develop a Wellhead Generating Unit

\section{RESULT AND DISCUSSION}

Based on the law. No. 21/2014, CHAPTER I, Article 1 , Section 1 reads "Geothermal energy is a source of heat energy contained in hot water, water vapor, and rocks along with associated minerals and other gases that are genetically inseparable in a Geothermal system. "

Geothermal energy is environmentally friendly with great potential and its utilization is not optimal, so it needs to be encouraged and increased in a planned and integrated manner in order to reduce dependence on fossil energy. The main focus in the implementation of geothermal energy is indirect use as a power plant in order to maintain the sustainability and security of national energy. Based on the law. No. 21/2014, CHAPTER I, Article 1, Section 11 reads "Indirect Use is an activity to exploit Geothermal Energy by going through a process of converting heat and / or fluid energy to electricity." Currently, the national energy demand is increasing along with the rapid economic growth so that to balance the availability of energy, the government will increase the role of geothermal utilization to reduce dependence on the role of fossil energy. One of the indirect uses of geothermal energy to meet Indonesia's electricity needs is by using the Geothermal Wellhead Generating Unit method. 


\subsection{Geothermal Wellhead Generating Unit Licensing Policy}

\subsubsection{Indirect Utilization Permit}

The Geothermal Wellhead Generating Unit is an indirect utilization of geothermal energy because the energy produced is electrical energy, but with a capacity that is not too large, around 5-10 MWe. So that the license granted is an Indirect Utilization Permit, which is in accordance with the Law. No. 21 of 2014, CHAPTER III, Article 9, Section 4 which reads "Exploitation of Geothermal for Indirect Use as referred to in Section (1) letter $b$ is used for generating electricity for self-interest or public interest.".

Apart from that, indirect utilization is also regulated in the PP. No. 7 of 2017 concerning Geothermal for Indirect Use. In accordance with PP. No. 7 of 2017, CHAPTER II, Article 2 reads "The implementation of Geothermal for Indirect Use in all parts of Indonesia is the authority of the Central Government which is implemented and or coordinated by the Minister." So that the Geothermal Wellhead Generating Unit permit is granted by the Minister, namely the Minister of Energy and Mineral Resources.

\subsubsection{Geothermal Wellhead Generating Unit Working Area Permit}

The Geothermal Wellhead Generating Unit work area can be divided into three types of Work Areas, namely:

- New Working Area, namely a Geothermal Working Area that has never been developed indirect geothermal activities in the area. This is in accordance with PP. No. 7 of 2017, CHAPTER II, Article 4 Section 2 which reads "The Minister determines the Work Area as referred to in Section (1) based on Geothermal Data and Information resulting from:
a. Preliminary survey; or
b. Preliminary Survey and Exploration. "

So that the work area of this type previously had to do a preliminary survey and exploration to see the potential of the work area whether the development of a Geothermal Wellhead Generating Unit could be carried out and then it would be determined by the Minister of Energy and Mineral Resources.

- Old Working Area, what is meant by the old working area is a Geothermal working area where geothermal activities have previously been carried out, both surveying and exploration, drilling and production. In Indonesia, usually the working area for the Geothermal Wellhead Generating Unit is an old working area or work area that has been previously worked on. Like in Kamojang and Dieng. Therefore, the applicable regulations are PP. No. 7 of 2017, CHAPTER II, Article 4 Section 3 which reads "Apart from the results of the preliminary survey and Preliminary Survey and Exploration as referred to in Section (2), the Minister can determine a Work Area based on the evaluation of geothermal exploitation activities from the returned Work Area."

So that for the development of the Geothermal Wellhead Generating Unit in this work area, an evaluation must first be carried out whether the work area is feasible and not detrimental.

The method used by the Minister in determining a Work Area is by means of an auction, the provisions concerning the procedures, bid conditions, procedures, preparation of documents and implementation of the auction are regulated in a Government Regulation. Based on Permen ESDM No. 11 of 2009 Article 2 Section 3 "The Minister, governors or regents / mayors in accordance with their authority shall bid for the Work Area as referred to in Section (1) to Business Entities by way of auction through printed media, electronic media and other media.". In carrying out the implementation of the Minister, the governor or regent / mayor in accordance with their respective authorities is obliged to form an odd numbered Working Area Tender Committee and at least 5 (five) people consisting of representatives from the Ministry of Energy and Mineral Resources, related agencies, Regional Governments, and representatives from Related Regional Agencies (Article 3 Section 1). The following (Figure 2) are the stages of conducting an auction for a WKP.

\subsubsection{Rules regarding the Exploration of Geothermal Wellhead Generating Unit}

UU. No. 21 of 2014, CHAPTER I, Article 1 Section 7 reads "Exploration is a series of activities covering geological, geophysical, geochemical investigations, test drilling and exploration well drilling with the aim of obtaining information on subsurface geological conditions in order to find and obtain estimates of Geothermal reserves."

Exploration to develop a Geothermal Wellhead Generating Unit is the same as conventional geothermal exploration. This is because searching for geothermal reserves is the same process, the difference is during the production process and the generation of electricity. Based on the Act. No. 21/2014, Article 31 "Exploration as referred to in Article 30 has a maximum period of 5 (five) years since the Geothermal Permit is issued and can be extended 2 (two) times, each for 1 (one) year." So that the total time given by the government to carry out exploration is 7 (seven) years. 
In carrying out preliminary surveys and exploration, it is carried out by the Minister (Permen ESDM No.37 of 2017 Article 5 Section 1) and can cooperate with public service agencies or BUMNs to finance and / or carry out exploration well drilling by the Central Government (Permen ESDM No. 37/2017 Article 5 Section 2). In addition, preliminary survey and exploration activities can be assigned to other parties in accordance with statutory regulations (Permen ESDM No. 37 of 2017 Article 6 Section 1-2).

In the case of exploration activity planning and budget, the IUP holder must submit it to the Minister c.q. Director General, Governor c.q. Provincial Technical

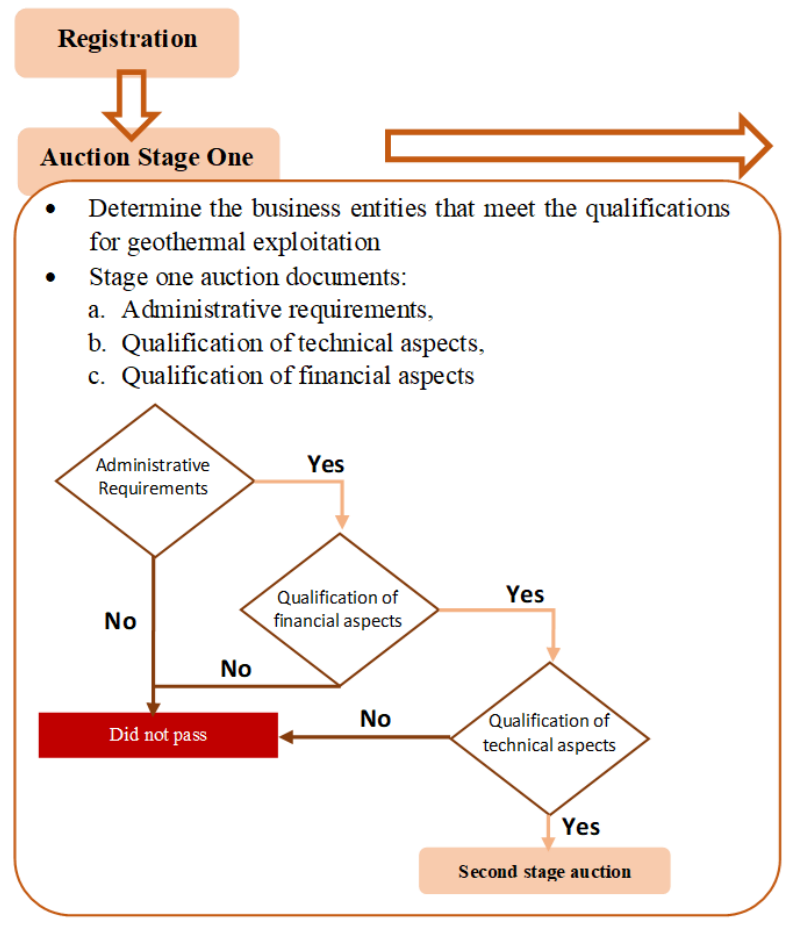

Figure 2 WKP Auction Stage

\subsubsection{Rules regarding Geothermal Exploitation of the Wellhead Generating Unit}

UU. No. 21/2014, CHAPTER I, Article 1 Section 8 "Exploitation is a series of activities in a certain Work Area which includes drilling development wells and reinjection wells, construction of field facilities and their supports, and Geothermal production operations."

Exploitation and utilization have a maximum period of 30 (thirty) years from the time the feasibility study is approved by the Minister (Article 32). Before being able to carry out exploitation and utilization, geothermal permit holders must:

a. Having an environmental permit in accordance with the provisions of laws and regulations in the field of environmental protection and
Service or Regent / Mayor c.q. District / City Technical Services in accordance with their respective authorities, no later than 2 (two) months before the work plan and annual expenditure budget run. (Permen ESDM No.11 of 2009 Article 10 Section 3)

If within the exploration period as referred to above, no reserves of geothermal energy that can be produced commercially are found, the IUP holder is obliged to return the entire Working Area to the Minister, Director General, Governor, Provincial Technical Service or

Regent / Mayor, Regency / District Technical Service. City according to its authority. (Article 21 Section 1)

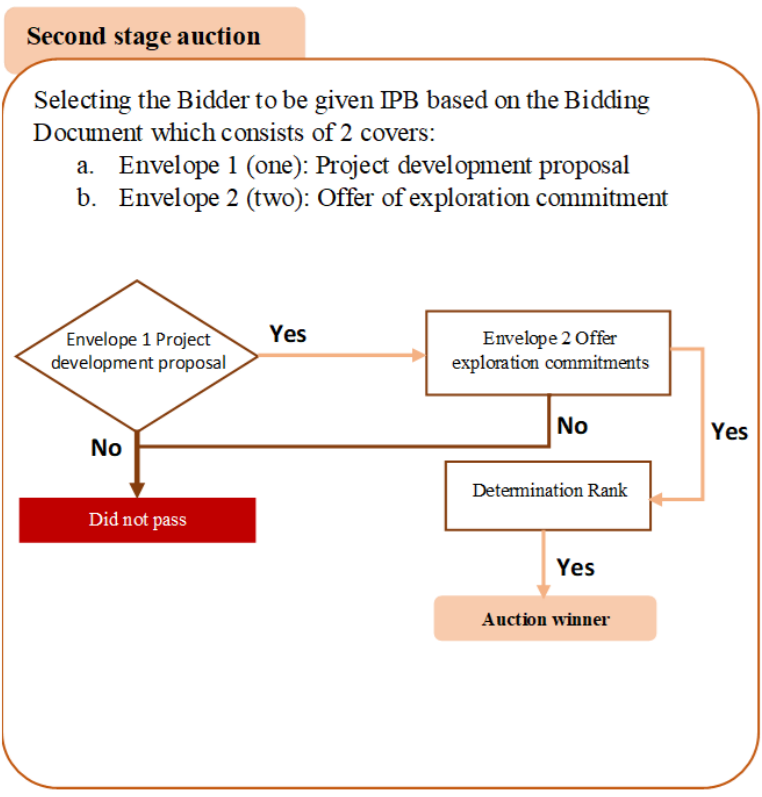

management which is included in the feasibility study.

b. Delivering the results of the feasibility study to the minister for approval

In general, exploitation activities for the Geothermal Wellhead Generating Unit are the same as conventional ones regulated in Permen ESDM No. 11 of 2009 Article 10 Section 3 "Before carrying out exploitation activities, IUP holders are required to provide a report on the results of a feasibility study in writing at the latest 1 (one) year after the completion of the feasibility study to the Minister c.q. Director General, Governor c.q. Provincial Technical Service or Regent / Mayor c.q. District / City Technical Service in accordance with their authority". However, what distinguishes between the two is the development plan. Based on Permen ESDM No. 11 of 2009 Article 10 Section 3 of the geothermal field 
development plan for electricity generation which includes:

\subsubsection{Determination of mine-worthy reserves throughout the Work Area;}

For the development of the Wellhead Generating Unit, the reserves that are categorized as feasible are $>25$ MWe. This is because the capacity to be generated is small.

\subsubsection{Application of appropriate technology for exploitation and capture of steam from production wells;}

The application of this technology is the main factor that differentiates it from conventional units, where the technology used in the Wellhead Generating Unit only requires one production and injection well, a short transmission pipe, a separator, a turbine, a condenser and a cooling tower, where all this equipment is located at the same location with a location that is not broad.

\subsubsection{Location of production wells;}

For the development of the Wellhead Generating Unit, the well location is only in the same location as the turbine and does not require many wells in other locations.

\subsubsection{Production and injection well design;}

For the development of the Wellhead Generating Unit, the production well design will be directed to a turbine to generate electricity. After the steam has condensed and cooled in the cooling tower, the condensate is injected into the earth using an injection well.

\subsubsection{Production well piping design;}

The most striking thing that distinguishes the Wellhead Generating Unit generator and the conventional one is the very short pipe design of 50-70 m (conventional is about hundreds of meters). This lowers the cost of building this type of plant.

\subsubsection{Short term and long-term production capacity planning; and}

Basically, the capacity that can be generated by the Wellhead Generating Unit is only on a small scale, which is about 5-10 MWe. In contrast to the conventional one which can generate 65-110 MWe by using many production wells.

\subsubsection{Power generation system.}

The power generation system also greatly affects the electrical capacity that can be generated in general, either a Wellhead Generating Unit or a conventional one using a separated cycle generator system or separation with a separator. However, for the maximum use of steam, it can also be combined using a binary cycle.

\subsection{Business Entity Development Wellhead Generating Unit (Small Scale)}

Business Entities are state-owned enterprises, regionowned enterprises, private enterprises, or cooperatives that are Indonesian legal entities and operate in the field of electricity supply.

In accordance with the Permen ESDM No. 23 Year 2017 The Business Entity that builds the Wellhead Generating Unit is required to do the things mentioned above, namely to prepare the production bonus amount according to the commercialized steam production. After the wellhead generating unit is in production, the business entity that develops it must take into account how much production bonuses will be given to the work area in accordance with applicable regulations.

In addition, business entities are also required to report the realization of sales of steam produced to the minister and also report if there is an excess or deficiency of the gross sales revenue to the Minister. If there is a deficiency or excess in the steam sales income, the business entity is obliged to report along with supporting files explaining the reasons for the deficiency or excess.

\subsubsection{Business Agency Rights and Obligations (Article 14)}

The Business Entity assigned to carry out its business must:

a. Make a business plan for the supply of electricity in accordance with the provisions of laws and regulations

b. Provides electric power in its business area

c. Strive to achieve an electrification ratio of at least 95\% within its business area within 5 years after receiving an assignment from the minister

d. Build electricity infrastructure and operate according to its function, no later than 1 year after receiving an assignment from the minister

e. Meet the provisions of the electricity safety and environment;

f. Provide electric power and electricity distribution networks with a good level of quality and reliability 
g. Report the electricity supply business activities in his business area every 6 months to the director general.

\subsubsection{Administrative Sanctions (Article 23)}

1. In the event that the business entity holding a business area in the business of providing electricity for a small scale does not carry out the obligations referred to in Article 14, the director general on behalf of the minister shall impose administrative sanctions in the form of:

a. Written warning: and / or

b. Revocation of business areas

2. Written warning shall be given a maximum of 3 times with a maximum warning period of 1 month

3. In the event that the holder of a business area in the business of providing electricity for a small scale who has received a written warning sanction after the end of the third written warning has not fulfilled his obligations, the director general on behalf of the minister shall impose administrative sanctions in the form of revocation of the business area

In accordance with the Permen ESDM no 382016 which regulates the business of providing small-scale electricity, business entities that develop well generating units for small scales have an obligation to optimize the use of sources, which means that business entities must be serious in developing wellhead generating units, namely by taking into account optimal production does not produce steam which is excessive for the sole benefit of damaging the reservoir.

Business entities must also pay attention to the environment in which their working areas pay attention to the $\mathrm{K} 3$ element even though they are only small-scale production because they still intersect with the surrounding area. If the business entity is not serious and neglects its obligations in developing the WGU, it will receive a reprimand and revocation of the area.

From the various statutory regulations on the exploitation of small-scale electricity supply above, it can be concluded that business entities are assigned by the minister or governor in carrying out their exploitation, the result of the exploitation as mentioned is to provide electricity to the regions.

\subsection{Aspects of Land Clearance for Dieng Wellhead Generating Unit}

Forest is an area that is overgrown with trees and other plants. Such areas are present in large areas of the world and function as reservoirs for carbon dioxide.

\subsubsection{The regulations governing the clearing of forest areas include:}

\subsubsection{Law No. 41 of 1999. about forestry}

(Section 1) "Forest is a unified system in the form of a stretch of land containing biological natural resources dominated by trees in their natural environment, which cannot be separated from one another".

(Section 2) "The provision as referred to in Section (1) letter $\mathrm{h}$ shall pay serious attention to local wisdom in each area"

\subsubsection{Law No. 32 year 2009 regarding Environmental Protection and Management.}

"Forbid someone to clear land by burning"

Considerations in the Opening of Forest Areas include several aspects including technical aspects, namely the opening of the area based on the most productive location based on the direction of the fracture from the reservoir. easy, labor costs and other costs. Ecological aspects, namely consideration can be seen from damage to the environment, damage to landscapes, danger of erosion and landslides, degradation of water quality and sedimentation.

\subsubsection{Licenses and Permits}

Law No 4/2009 on Minerba

Mining areas are categorized and designated as Mining Business License Areas (WIUP).

The license is issued by the Ministry of Energy and Mineral Resources (ESDM), the governor or district head depending on the scale of the mining operation.

\subsection{Wellhead Generating Unit Steam and Electricity Sale-Purchase Agreement}

Legislations regarding the rules for electricity distribution, production bonus rules and sale and purchase agreements relating to the small-scale business of the Wellhead Generating Unit (WGU).

\subsubsection{Rules Regarding the Distribution of Electricity include:}

\subsubsection{Regulation of the Minister of Energy and Mineral Resources Number 27 of 2017}

Regulation of The Minister of Energy and Mineral Resources Concerning Service Quality Levels and Fees Related to The Distribution of Electricity By $\mathrm{Pt}$ Perusahaan Listrik Negara (Persero). 


\subsubsection{Law Number 30 of 2009 (LAWS ON ELECTRICITY.)}

Article 12, The business of providing electricity for self-interest as referred to in Article 9 letter b includes:

a. electric power generation;

b. electric power generation and distribution of electricity; or

c. electric power generation, electric power transmission, and electric power distribution.

Article 13, The business of providing electricity for self-interest as referred to in Article 12 can be carried out by government agencies, regional governments, stateowned enterprises, regionalowned enterprises, private enterprises, cooperatives, individuals and other institutions / business entities.

Article 14, Further provisions regarding the electricity supply business as referred to in Article 9 to Article 13 shall be regulated in a Government Regulation.

Based on article 12, article 13, and article 14, Law Number 30 of 2009 concerning Electricity, it can be concluded that for small scale Wellhead Generating Unit (WGU) operations, it must follow the existing rules in the law. namely providing electricity for its own interests other than for public or customer interests. The distribution of electricity from the production of wellhead generating units on a small scale can be distributed to local agencies, local governments, state-owned enterprises, regional-owned enterprises, private enterprises, cooperatives, individuals, and other institutions / business entities, but only a few agencies can receive the production of small-scale wellhead generating units. This is because the production results from this small-scale wellhead generating unit only produce an estimate of less than $10 \mathrm{MW}$. The bonus generated will also be small compared to large-scale generators of more than $10 \mathrm{MW}$.

\subsubsection{ESDM Regulation Number 10 Year 2017}

Regulation of The Minister of Energy and Mineral Resources Concerning The Mains of Electricity Sale and Purchase Agreement.

Article 2

1. This Ministerial Regulation regulates the provisions regarding the principles in the PJBL between PT PLN (Persero) as the buyer and the Business Entity as the seller of the Electric Power System.

2. The points stipulated in the PJBL as referred to in Section (1) cover the commercial aspects of all types of power plants, including geothermal power plants, hydropower plants and biomass power plants.

3. The points regulated in the PJBL for intermittent new energy and renewable energy power plants, hydroelectric power plants below $10 \mathrm{MW}$ (ten megawatts), biogas power plants, and municipal waste-based power plants are regulated in a Ministerial Regulation

Article 5

1. The business entity as the seller has the right to:

a. Receive payments related to the selling price of electricity according to the PJBL;

b. Get incentives for accelerated COD implementation if the said acceleration is at the request of PT PLN (Persero); and

c. Get deemed dispatch if the PT PLN (Persero) network is disrupted, it is not due to force majeure.

2. The business entity as the seller is obliged to:

a. Designs, funds, builds, owns, operates, and transfers power plants, and may include the transmission of electric power if required;

b. Provide guarantees in the form of project implementation guarantees, and performance guarantees in the form of penalties;

c. Pay penalties for failure to achieve performance guarantees as referred to in letter $\mathrm{b}$, including penalties for late implementation of cod;

d. Submitting a monthly electricity supply plan (projected af);

e. Sending and selling electricity to pt pln (persero) in accordance with the electricity supply plan (projected af);

f. Take care of all the necessary permits;

g. Comply with the provisions of the domestic component level;

h. Maintain the continuity of electricity supply during the pjbl period; and

i. Pay a penalty in accordance with the applicable provisions.

3. Further provisions regarding the rights and obligations of the Business Entity as the seller are contained in the PJBL

Article 6

1. PT PLN (Persero) as the buyer has the right to:

a. Obtaining reliable and sustainable power supply from the power plant; and 
b. Obtain any necessary approvals with respect to pjbl 2. PT PLN (Persero) as the buyer must:

- Provide incentives for accelerating COD implementation to business entities if the said acceleration is at the request of PT PLN (Persero);

- Absorb and buy electricity generated by the Business Entity in accordance with the PJBL which has been agreed upon for a certain period;

- Pay deemed dispatch if PT PLN (Persero) 's electricity network is disrupted not due to force majeure reasons; and

- Maintain and maintain the reliability of network facilities to receive electricity from the Business Entity.

In accordance with the Regulation of the Minister of Energy and Mineral Resources Number 10 of 2017 concerning the Principles of the Electricity Sale and Purchase Agreement, the Small-scale Wellhead Generating Unit (WGU) business entity must follow the rules or principles in the power purchase agreement. The wellhead generating unit business entities that are built on a small scale must meet the provisions regarding the rights and obligations of PT PLN (Persero) as the buyer as outlined in the electricity buying and selling regulations.

In addition, PT PLN (Persero) and the Business Entity have considered the repayment period of costs previously borrowed for business needs at the beginning and if the production period has been carried out, the costs previously borrowed must be returned to the lender.

\subsection{Analysis of Environmental Impact Problems (AMDAL) for the Wellhead Generating Unit (Small Scale)}

\subsubsection{Definition of AMDAL}

AMDAL is an instrument for planning preventive actions against pollution and environmental damage that may result from development activities. Given its function as an instrument in business and / or activity planning, EIA preparation is not carried out after the business and / or activity has been carried out. The preparation of the EIA as referred to in this Section is carried out at the stage of a feasibility study or a detailed engineering design.

\subsubsection{AMDAL regulations}

1. Government Regulation of the Republic of Indonesia Number 27 of 1999 concerning
Environmental Impact Analysis. Enacted on May 7, 1999.

2. Decree of the State Minister for the Environment Number 86 of 2002 concerning Guidelines for Implementing Environmental Management Efforts and Environmental Monitoring Efforts. Enacted on October 28, 2002.

3. Decree of the State Minister for the Environment No. 17/2001 concerning Types of Business Plans and / or Activities that Require an Environmental Impact Analysis. Enacted on May 22, 2001.

4. Decree of the Minister of State for the Environment No. 4 of 2001 on Guidelines for Preparation of AMDAL for Integrated Settlement Development Activities. Enacted on February 21, 2000.

\subsubsection{AMDAL Obligations}

Article 2 Section (2) Permen lh Types of Mandatory EIA, stipulates that, "Types of business plans and / or activities that are required to have EIA as referred to in Section (1) are listed in Appendix I which is an integral part of this Ministerial Regulation".

Furthermore, according to Article 3 Section (1) the Business Plan and / or Activities carried out:

a. Inside protected areas; and / or

b. Directly adjacent to a protected area, it is also defined as an activity that is mandatory to have an amdal.

\subsubsection{Eligibility requirements to fulfill the AMDAL}

Article 36 Section 1 of Law Number 32 of 2009 concerning Environmental Protection and Management (UUPPLH) states that "Every business and / or activity that is required to have an Amdal or UKL-UPL is required to have an environmental permit".

\subsubsection{Sanctions that do not comply with the AMDAL}

1. Every business and / or activity that is required to have an Amdal or UKL-UPL must have an environmental permit (Article 36 Section (1) of Law Number 32 of 2009 concerning Environmental Protection and Management) whoever violates can be subject to criminal penalties as stipulated in the provisions. Article 109 Section (1) of Law Number 32 of 2009

2. "Every person who carries out a business and / or activity without an environmental permit as referred to in Article 36 Section (1), shall be 
punished with imprisonment for a minimum of 1 (one) year and a maximum of 3 (three) years and a fine of at least Rp1. .,000,000,000.00 (one billion rupiah) and a maximum of $\mathrm{Rp}$. 3,000,000,000.00 (three billion rupiah) ". (Article 109 Section (1) UUPPLH)

3. "Officials issuing business and / or activity permits that issue business and / or activity licenses without environmental permits as referred to in Article 40 Section (1) shall be subject to imprisonment of 3 (three) years and a maximum fine of Rp. 3. 000,000,000.00 (three billion rupiah)". (Article 111 Section (2) UUPPLH)

4. Geothermal waste management regulations

5. Regulation of the Minister of Energy and Mineral Resources of the Republic of Indonesia Number 21 of 2017 concerning Management of Drill Mud and Drill Cutting Waste in Geothermal Drilling

\subsubsection{Regulations Regarding Geothermal Emissions}

PermenLHK No. P.15 / MENLHK / SETJEN / KUM.1 / 4/2019 concerning Emission Standards for Thermal Power Plants ("PermenLHK 15/2019")

\subsection{Rules Regarding the Role Of The Community Towards The Impact Of PLTP On The Environment}

This is the fullness of Chapter VII Article 165 regarding community participation in exploitation and utilization of geothermal energy as stated in Law No. 21/2014, Article 165 explains that:

1. In the implementation of Geothermal administration, the community has a role to participate in:

a. Maintain, protect, and maintain the preservation of the area of Geothermal exploitation activities;

b. Submit reports on the occurrence of hazards, pollution, and / or environmental damage in the area of Geothermal exploitation activities.

2. In the implementation of Geothermal administration, the community has the right to:

a. obtain information related to Geothermal exploitation through the Government or Regional Government in accordance with their respective authorities; b. obtain benefits from geothermal exploitation activities

c. obtain adequate compensation due to errors in Geothermal exploitation activities in accordance with the provisions of laws and regulations; and filed a lawsuit against the court against losses due to Geothermal exploitation activities that violated the provisions.

\section{CONCLUSION}

The following are the conclusions of this paper:

1. Wellhead Generating Unit (Small Scale) is an indirect utilization of Geothermal energy whose development permit is directly regulated by the central government, namely the Minister of Energy and Mineral Resources.

2. In implementing WGU, the business entity is obliged to optimize production and has the right to cooperate with other business entities and in its implementation the business entity is supervised by the Minister and may be subject to sanctions if the utilization is not optimal.

3. An Environmental Impact Analysis (AMDAL) is carried out to maintain the quality of the environment so that it is not damaged by development activities. Environmental Impact Analysis (AMDAL) is a study of the major and significant impacts of a planned business and / or activity on the environment required for the decision-making process regarding the conduct of a business and / or activity in Indonesia. AMDAL is an environmental management instrument that must be compiled by activity / business operators carrying out activities / businesses that are included in the AMDAL compulsory list.

4. Legal protection in terms of the power purchase agreement in order to increase the supply of electricity to the public is also necessary for law enforcement in the electricity sector. The government and regional governments have the authority to provide guidance and supervision to the implementation of small scale Well Head Generating Unit (WGU) businesses in electricity, including the implementation of supervision in the engineering sector.

5. Clearance of forest areas aims to manage natural resources in the form of geothermal systems that are contained underneath. Due to the location and direction of the fractures that cannot be regulated, the construction is carried out as close as possible to the direction of the fractures on the surface by taking into account technical, economic and ecological aspects. 


\section{ACKNOWLEDGMENTS}

The authors would like to sincerely acknowledge all people who have supported us in the writing of this paper.

\section{REFERENCES}

[1] A. Isa, Planning for Forest Road Network Development, Pontianak: Faculty of Forestry, 2003.

[2] Elias, Forest Area Opening Training, Faculty of Forestry, Bogor Agricultural University, Modules 8 and 9. Planning for Forest Area Opening, Bogor: Bogor Agricultural University, 2007.

[3] https://cpssoft.com/blog/bisnis/pengertian-badanusaha-bentuk-badan-usaha-yangada-di-indonesia/

[4] https://padangkita.com/beberapa-dampak-yangditimbulkan-pembangkit-listrikgeothermal/.

[5] Oka and S. Kusumo, Guidelines for the Construction of Forest Transport Roads, Perhutani's LPHH Assistant Project: East Java, East Java, 1972.

[6] Regulation of the Minister of Energy and Mineral Resources Number 10 of 2017 concerning Regulation of the Minister of Energy and Mineral Resources concerning the Principles of the Power Purchase Agreement (State Gazette of the Republic of Indonesia of.

[7] Government Regulation no. 7/2017 on Geothermal for Indirect Use.

[8] Government Regulation of the Republic of Indonesia Number 28 of 2016 concerning Government Regulation concerning Amounts and Procedures for Giving Geothermal Production Bonuses (State Gazette of the Republic of Indonesia of 2016 Number 136 Supplement $t$.

[9] Presidential Regulation No. 22/2017 concerning the General Plan for National Energy.

[10] Permen ESDM No. 23 Year 2017 concerning Procedures for Reconciliation, Deposit and Reporting of Geothermal Production Bonuses.
[11] Permen ESDM No. 38 of 2016 concerning the Acceleration of Electrification in Undeveloped, Remote, Border and Small Island Populated Villages through the Implementation of SmallScale Electricity Supply Business.

[12] Permen ESDM No.11/2009 concerning the Implementation of Geothermal Business Activities.

[13] PERMEN ESDM no. 21/2017 concerning the management of drilling mud and cuttings waste in geothermal drilling.

[14] Permen ESDM No. 37/2017 concerning Geothermal Working Area for Indirect Use.

[15] P. Lia, Techno-Economic Study of Small-Scale Geothermal Power Plants: Wellhead Generating Unit, Electricity and Renewable Energy Vol. 18 No. June 1, 2019: 41 - 50. 2019.

[16] M. I. Said, Forest Exploitation, Pontianak: Faculty of Agriculture, University of Tanjungpura, 1986.

[17] Sofyan, Basics of Forest Road Construction, Introduction to Technical Culture Section 1. Fahutan Foundation, Yogyagkarta: Gajahmada University, 1976.

[18] Law Number 32 of 2009 concerning Environmental Protection and Management (UUPPLH).

[19] Law No. 21 of 2014 concerning Geothermal Energy.

[20] Law Number 21 of 2014 concerning Law concerning Geothermal Energy (State Gazette of the Republic of Indonesia of 2014 Number 217 Supplement to the State Gazette of the Republic of Indonesia Number 5585).

[21] Law Number. 30 of 2009 concerning Electricity (State Gazette No.133. Additional to the State Gazette No. 5052).

[22] S. I. H. Widodo, Principles and Practices of Forest Harvesting in Indonesia. Ministry of Forestry and Plantation and Natural Resources Management Program., 2000. 